\title{
Т.А. СОЛОВЬЕВА
}

\section{КИНОИСКУССТВО КАК МЕТОД ФОРМИРОВАНИЯ НАЦИОНАЛЬНОГО САМОСОЗНАНИЯ}

\begin{abstract}
Ключевые слова: чувашский фрильм, трест "Чувашкино», визуальное восприятие, национальное самосознание, Чувашская автономная область.

В статье рассматривается один из важнейших этапов в процессе фрормирования национального самосознания чувашского народа, пришедшийся на начало XX в. Образование 24 июня 1920 г. Чувашской автономной области поставило перед руководством нового национально-государственного образования непростую задачу по консолидации населения и укреплению чувства принадлежности к единой нации. Отмечается, что основу национальной политики данного периода составили обращение к общему историческому прошлому и поддержка культурно-просветительских начинаний, в частности создание кинематограффа как сильнейшего средства визуального воздействия. На примере первого чувашского художественного кинофильма «Волжские бунтари» (1926) прослеживается глубокое эмоциональное воздействие демонстрации образов традиционного быта и обрядов на широкую зрительскую аудиторию. На основе архивных документов делается вывод, что съемки и выход картин в прокат сыграли определенную роль в становлении национальной идентичности чувашского народа, давая повод гордиться своей культурой и знакомить с ней зрителей за пределами региона.
\end{abstract}

Революционные события 1917 г. активизировали многие народы России на поиск форм национального самоопределения. «Декларация прав народов России», принятая 2 ноября 1917 г., подтвердила равенство и суверенность всех народов, их право на свободную самоидентификацию. В тот же период для осуществления национальной политики был образован Народный комиссариат по делам национальностей. Данные меры позволили создать правовое поле и организационные структуры для национально-государственного строительства.

Истоки формирования идей национальной идентичности чувашского народа восходят ко второй половине XIX в. Во многом они связаны с именем просветителя чувашского народа И.Я. Яковлева и созданной им Симбирской чувашской учительской школой [11. С. 7], в дальнейшем свою роль сыграли издание в 1906-1907 гг. первой газеты на чувашском языке «Хыпар», деятельность активистов национальных движений коренных народов Поволжья [3. С. 29] и ряд других фракторов.

В результате длительной подготовительной работы и нарастания общественно-политической активности 24 июня 1920 г. была создана Чувашская автономная область. Вместе с тем юридическое оформление национальнотерриториального объединения не означало мгновенной и окончательной консолидации ее населения. Как и всякому процессу, затрагивающему сознание большого числа людей, ей требовалось время, а также определенные меры поддержки со стороны правительства. Одной из таких мер стала организация чувашского кинематографа. 
В 1926 г. в широкий прокат вышел первый чувашский художественный фрильм «Волжские бунтари». Картина произвела сильное впечатление на жителей республики и получила многочисленные отзывы как в центральной, так и в местной прессе. Фильм, повествовавший о событиях периода Первой русской революции и Гражданской войны, с успехом шел в прокате не только на территории республики, но и на экранах всей страны.

Накануне 20-летия Первой русской революции 1905-1907 гг. на областном партийном съезде было принято решение создать художественное произведение о революционной борьбе. За воплощение идеи с большим энтузиазмом взялся И.С. Максимов-Кошкинский, за плечами которого на тот момент уже был опыт организации первого профессионального чувашского театра. В короткие сроки он подготовил сценарий, в основу которого легли революционные выступления крестьян с. Исмели Чебоксарского уезда (ныне с. Октябрьское Мариинско-Посадского района Чувашской Республики) в 1906 г.

Правительство республики поддержало это творческое начинание, однако за неимением технической базы обратилось за помощью в создании фильма к кинофабрикам Москвы, Ленинграда и Харькова. На призыв откликнулось Северо-Западное областное управление по делам фотографии и кинематографии («Севзапкино»), расположенное в Ленинграде. 31 августа 1925 г. ЦИК Чувашской АССР заключил с ним договор, согласно которому большую часть расходов по фильму брало на себя «Севзапкино». Это налагало определенные условия: утверждение режиссера и подбор актеров оставались за ленинградцами, им же полагались и все доходы от демонстрации фильма за пределами республики. Для Чувашии предполагалось изготовить один экземпляр с чувашскими титрами [5. Л. 9].

Производство фильма «Волжские бунтари» положило начало организации треста по производству художественных и документальных фрильмов «Чувашкино». Он стал одной из первых национальных киноорганизаций страны и сыграл заметную роль в становлении советского киноискусства. Субсидии из местного бюджета, выданные на производство первых кинокартин, стали безвозвратной ссудой, обращенной впоследствии в уставной капитал киностудии [6. Л. 61].

Относительно кандидатуры на должность руководителя студии сомнений не возникало, им стал И.С. Максимов-Кошкинский, совмещавший работу режиссера, актера и сценариста. Под его началом развернулись съемки следующих картин. Во втором фрильме «Сарпике», который начали снимать в 1926 г., главные роли исполнили Максимов-Кошкинский и его супруга Тани Юн. К съемке третьего фрильма «Хура юпа» (Черный столб) (1927 г.) было привлечено еще больше чувашских артистов. Четвертый фрильм «Атӑл суинчи тӑвӑл» (Вихрь на Волге) (1928 г.) ставился почти исключительно силами национальных кадров. В 1930 г. началась демонстрация пятого фильма «Апайка» (Прачка), в том же году был снят фильм «Священная роща». Он оказался последним для «Чувашкино». Осенью 1930 г. студия влилась во вновь организованное «Востоккино» и прекратила свое существование. Последний чувашский фрильм «Асту!» (Помни!) уже в производстве «Востоккино» вышел в 1932 г.

С момента появления «Чувашкино» систематически снимало и кинохронику, освещающую самые значимые события: строительство промышленных предприятий, дорожное строительство, первомайские демонстрации и отдельные события в деревне. За довольно короткий срок (1926-1932 гг.) на студии было создано семь художественных и три документальных фильма. 
К сожалению, огромный культурный пласт, запечатленный киностудией на пленку, был безвозвратно утерян в конце 1930-х гг., когда И.С. МаксимоваКошкинского и Тани Юн обвинили в национализме и подвергли репрессиям (в 1940 г. их освободили, реабилитировали в 1956 г.). В числе уцелевших оказалась лишь «Священная роща» и отдельные части ряда картин [2. С. 98].

В фрондах Государственного исторического архива Чувашской Республики сохранились сведения о съемках этих фильмов. Особый интерес среди них представляют свидетельства зрителей кинокартины «Волжские бунтари», благодаря которым можно восстановить некоторые ее художественные особенности.

Съемки фильма проходили в основном в Чебоксарах и его окрестностях. Режиссером картины стал П.П. Петров-Бытов, впоследствии известный советский кинорежиссер, автор фильмов «Пугачев», «Разгром Юденича» и др. Главные роли исполнили актеры, набранные «Севзапкино». В эпизодах снимались и чувашские артисты: Георгий Парне, Кирилл Егоров, Максимов-Кошкинский и Тани Юн, запомнившаяся зрителям в небольшой роли матери. В массовых сценах участвовали крестьяне из окрестных деревень и воспитанники Чебоксарской школы-коммуны. Для съемок были использованы подлинные национальные костюмы, выкупленные у населения, а также церковная утварь из уже закрытых на тот момент монастырей. Фильм вышел под совместной маркой киностудий «Севзапкино» и «Чувашкино», хотя последняя была официально оформлена только в декабре 1927 г.

По сюжету главный герой картины - сельский учитель по имени Хури был заключен в тюрьму за участие в революционных событиях 1905-1907 гг. Царские войска под руководством казанского вице-губернатора Д.Д. Кобеко жестко подавили восстание. Однако главному герою с помощью товарищей удалось сбежать, совершить неудачную попытку покушения на вице-губернатора и покинуть страну. По возвращении его вновь арестовали и отправили на каторгу. В конце фильма освобожденный революцией 1917 г. Хури погиб во время захвата Казани войсками белочехов [1. С. 343].

Прообразом героя фильма считался Тимофей Николаевич Николаев (Хyри) - эсер, один из самых ярких представителей чувашского национального движения, который в отличие от экранного прототипа был расстрелян большевиками в Казани. Во время Первой русской революции он возглавлял Казанский комитет партии эсеров, выступал за национальную автономию для чувашей, за что получил прозвище «президент Чувашской Республики» [9. С. 165].

По воспоминаниям его современника эсера С.Н. Николаева, Хури, будучи «высоким, статным, красивым брюнетом с черными большими глазами, выделялся во всякой толпе», совершал отчаянные поступки, граничившие с безрассудством, и рьяно пропагандировал свои идеи [10. С. 242]. Образ во всех отношениях подходил для воплощения на экране. В советское время его высказывания относительно некоторых действий большевиков замалчивались, благодаря чему он приобрел романтический ореол национального героя и репутацию легендарного революционера.

Первый показ фильма в Чебоксарах состоялся 22 июня 1926 г. и совпал с днями ежегодных ярмарок. Картину демонстрировали в здании Чувашского театра. Приезжие крестьяне буквально осаждали театр, вся свободная территория вокруг была заставлена их телегами. Газета «Канаш» писала в эти дни: «Фильм "Волжские бунтари"» рассказывает о жизни чуваш, об их делах и обы- 
чаях в незабываемых художественных картинах. Он состоит из пролога, эпилога и 8 частей. Кроме показа событий 1905-1907 гг. здесь с большой достоверностью изображены некоторые бытовые подробности и обряды, например, «Чўк», «Акатуй» и т.д. Картина имеет большое значение в деле поднятия культурного и политического уровня чувашского крестьянства...» [4].

Вопреки ожиданиям авторов постановка не принесла прибыли, однако имела ощутимый художественный и политический эфффект [7. Л. 3]. Весной 1928 г. кинопередвижку с фрильмом «Волжские бунтари» с надеждой на дополнительную прибыль отправили в повторный прокат по северным районам республики.

На местах основными площадками для работы кинопередвижек служили здания школ, куда на киносеансы собирались жители всех окрестных сел и деревень. По отзывам одного из очевидцев премьерного показа в Чебоксарах в 1926 г., фильм отправился в сельский прокат в несколько урезанном виде [8. Л. 52], однако все равно оказал колоссальное впечатление на аудиторию.

Для 1920-х гг. кино для деревни было большим событием, и многие сельчане, особенно пожилые, знакомились с этим видом искусства впервые («кино для деревни является большой новостью», - писали жители д. Аксарино Мариинско-Посадского района) [8. Л. 40].

Фильм пользовался большой популярностью. Как сообщают документы, несмотря на весеннюю распутицу, залы были заполнены до отказа, подчас не умещая всех желающих прикоснуться к синематографу. Цены на билеты варьировались от 5 до 10 коп. для детей и 10-15 коп. - для взрослых и были доступны широким слоям населения.

Зрители проявляли большой интерес к сценам традиционного уклада жизни чувашей, где, как они отмечали, с большой достоверностью изображались «старинные обряды и верования». «Особенно публика заинтересовалась бытовой стороной картины - Акатуй, Чўк, другие праздники; поучителен домашний способ лечения детей», - писал в отзыве председатель Нижерского сельсовета Козловского района Васильев [8. Л. 42].

Жители д. Сятракасы Мариинско-Посадского района оставили следующую запись: «Кинокартина является средством поднятия культурного уровня в нашей отсталости. Имея счастье увидеть впервые кино в деревне только в 1928 г. собравшиеся надеются, что в дальнейшем чувашское кино не забудет нас посещать...» [8. Л. 51].

По свидетельствам очевидцев восстания, события которого легли в основу сюжета, в фильме нашли отражение многие не соответствовавшие действительности художественные допущения. К примеру, зрители с. Карачево Козловского района писали: «Картина сама по себе никаких дефектов не имеет, за исключением разве излишних прибавлений, коих не было на самом деле: ведь восстание в Исмелях, в базарный день, имеет еще живых свидетелей, и по их отзывам стрельбы из пушек никогда не было» [8. Л. 50]. Недовольство вызывали также некоторые географические неточности и излишняя наигранность, присущая части драматических сцен.

Максимов-Кошкинский в последующем и сам отмечал, что изобилие национальных обрядов мешало обстоятельному развитию основной сюжетной линии, не всегда удачно сочетавшей подлинно исторические события с авторским вымыслом. Тем не менее широкое освещение в фильме традиционных верований, обычаев и культуры, привлечение к съемкам чувашских акте- 
ров и местного населения к массовым сценам, обращение к известным сюжетам недавнего прошлого, воспоминания о которых были еще свежи в памяти современников, определили успех картины.

Безусловно, филльм «Волжские бунтари», как первый опыт создания кино, не был лишен недостатков, но он положил начало истории кинематографии в Чувашии и способствовал подъему национального самосознания чувашского народа. Местная публика не скрывала гордости за чувашскую культуру, покорившую новую высоту, а зрители по всей стране, посмотревшие фрильм, познакомились с традиционными обрядами и сюжетами из истории Чувашского края. Сегодня мы не имеем возможности увидеть черно-белые кадры той ленты, но благодаря отзывам зрителей можем представить, какое впечатление на жителей республики произвел первый в истории чувашский художественный фильм.

\section{Литература}

1. Алексеев В.Н. Волжские бунтари // Чувашская энциклопедия: в 4 т. Чебоксары: Чуваш. кн. изд-во, 2006. Т. 1. С. 343.

2. Антонов Н.К. Из истории «Чувашкино» // Ученые записки ЧНИИ. Вып. 35. Чебоксары: ЧНИИ ЯЛИ, 1967. С. 98-109.

3. Булдаков В.П. Кризис империи и революционный национализм начала $\mathrm{XX}$ в. в России // Вопросы истории. 2000. № 1. С. 29-45.

4. Волжские бунтари // Канаш, 1926. 23 июня.

5. Государственный исторический архив Чувашской Республики (далее - ГИА ЧР). Ф. Р-147. Оп. 1. Д. 364.

6. ГИА ЧР. Ф. Р-483. Оп. 1. Д. 2.

7. ГИА ЧР. Ф. Р-483. ОП. 1. Д. 4.

8. ГИА ЧР. Ф. Р-483. Оп. 1. Д. 7.

9. Клементьев В.Н. Истоки государственности чувашей. Чебоксары: Новое время, 2014. 318 с.

10. Научно-справочная библиотека ГИА ЧР. Воспоминания С.Н. Николаева. Прага: Русская радиция, 2015. 572 с.

11. Сергеев Т.С. Научно-педагогическое наследие И.Н. Ульянова и современность. М.: МГГУ имени М.А. Шолохова, 2009. 288 с.

СОЛОВЬЕВА ТАТЬЯНА АНАТОЛЬЕВНА - НачаЛЬНИк отдеЛа испоЛЬЗОВания документов, Государственный исторический архив Чувашской Республики, Россия, Чебоксары (ts1109p@yandex.ru).

\section{Tatyana A. SOLOVYOVA \\ CINEMATOGRAPHIC ART AS A METHOD OF NATIONAL IDENTITY FORMATION}

Key words: Chuvash film, trust "Chuvashkino", visual perception, national identity, the Chuvash Autonomous Region.

The article discusses one of the most important stages in the process of national identity formation of the Chuvash people, which occurred at the beginning of the $20^{\text {th }}$ century. Formation of the Chuvash Autonomous Region on June 24, 1920 set the leadership of the new national state a challenge to consolidate the population and to reinforce the sense of belonging to one nation. It is noted that the basis of the national policy of this period was the appeal to the general historical past and support for cultural and educational endeavors, in particular 
creation of cinematography as the strongest means of visual perception. The example of the first Chuvash feature film "The Volga Buntari" (1926) traces the deep emotional impact of demonstrating traditional life and rituals images to a wide audience. On the basis of archival documents it is concluded that shooting and release of films played a certain role in forming the national identity of the Chuvash people, giving reason to be proud of its culture and to introduce it to viewers outside the region.

\section{References}

1. Alekseev V.N. Volzhskie buntari [Rebels from the Volga]. In: Chuvashskaya entsiklopediya: v 4 t. [Chuvash encyclopedia. 4 vols.]. Cheboksary, Chuvash Publ. House, 2006, vol. 1, p. 343.

2. Antonov N.K. Iz istorii "Chuvashkino» [The history of the "Chuvashkino"]. In: Uchenye zapiski Chuvashskogo nauchno-issledovatel'skogo instituta. Vyp. 35 Scientific notes of the Chuvash research Institute. Iss. 35]. Cheboksary, 1967, pp. 98-109.

3. Buldakov V.P. Krizis imperii i revolyutsionnyi natsionalizm nachala XX v. v Rossii [The crisis of Empire and revolutionary nationalism of the early $20^{\text {th }}$ century in Russia]. Voprosy istorii, 2000, no. 1, pp. 29-45.

4. Volzhskie buntari [Volga rebels]. Kanash, 1926, June 23.

5. Gosudarstvennyi istoricheskii arkhiv Chuvashskoi Respubliki. F. R-147. Op. 1. D. 364 [The State Historical Archives of the Chuvash Republic. Archives R-147. Anagraph 1. Document 364].

6. Gosudarstvennyi istoricheskii arkhiv Chuvashskoi Respubliki. F. R-483. Op. 1. D. 2. [The State Historical Archives of the Chuvash Republic. Archives R-483. Anagraph 1. Document 2].

7. Gosudarstvennyi istoricheskii arkhiv Chuvashskoi Respubliki. F. R-483. Op. 1. D. 4 [The State Historical Archives of the Chuvash Republic. Archives R-483. Anagraph 1. Document 4].

8. Gosudarstvennyi istoricheskii arkhiv Chuvashskoi Respubliki. F. R-483. Op. 1. D. 7 [The State Historical Archives of the Chuvash Republic. Archives R-483. Anagraph 1. Document 7].

9. Klement'ev V.N. Istoki gosudarstvennosti chuvashei [The origins of Chuvash statehood]. Cheboksary, Novoe vremya Publ., 2014, 318 p.

10. Nauchno-spravochnaya biblioteka Gosudarstvennogo istoricheskogo arkhiva Chuvashskoi Respubliki. Vospominaniya S.N. Nikolaeva [Scientific reference library of the State Historical Archives of the Chuvash Republic. Memoirs of S. N. Nikolaev]. Prague, 2015, 572 p.

11. Sergeev T.S. Nauchno-pedagogicheskoe nasledie I.N. Ul'yanova i sovremennost'. [Scientific and pedagogical heritage of I. N. Ulyanov and modernity]. Moskva, 2009, 288 p.

TATYANA A. SOLOVYOVA - Head of the Department of Document Use, State Historical Archives of the Chuvash Republic, Russia, Cheboksary (ts1109p@yandex.ru).

Формат цитирования: Соловьева Т.А. Киноискусство как метод формирования национального самосознания // Исторический поиск. - 2020. - T. 1, № 3. - C. 114-119. DOI: 10.47026/2712-9454-2020-1-3-114-119. 